\title{
The influence of psychological factors on health- related quality of life after stroke: a systematic review
}

Citation for published version (APA):

van Mierlo, M. L., Schroder, C., van Heugten, C. M., Post, M. W. M., de Kort, P. L. M., \& Visser-Meily, J. M. A. (2014). The influence of psychological factors on health-related quality of life after stroke: a systematic review. International journal of stroke, 9(3), 341-348. https://doi.org/10.1111/ijs.12149

Document status and date:

Published: 01/04/2014

DOI:

10.1111/ijs. 12149

Document Version:

Publisher's PDF, also known as Version of record

Document license:

Taverne

Please check the document version of this publication:

- A submitted manuscript is the version of the article upon submission and before peer-review. There can be important differences between the submitted version and the official published version of record.

People interested in the research are advised to contact the author for the final version of the publication, or visit the DOI to the publisher's website.

- The final author version and the galley proof are versions of the publication after peer review.

- The final published version features the final layout of the paper including the volume, issue and page numbers.

Link to publication

\footnotetext{
General rights Owners
rights.

- You may freely distribute the URL identifying the publication in the public portal. please follow below link for the End User Agreement:

www.umlib.nl/taverne-license

Take down policy

If you believe that this document breaches copyright please contact us at:

repository@maastrichtuniversity.nl

providing details and we will investigate your claim.
}

Copyright and moral rights for the publications made accessible in the public portal are retained by the authors and/or other copyright owners and it is a condition of accessing publications that users recognise and abide by the legal requirements associated with these

- Users may download and print one copy of any publication from the public portal for the purpose of private study or research.

- You may not further distribute the material or use it for any profit-making activity or commercial gain

If the publication is distributed under the terms of Article $25 \mathrm{fa}$ of the Dutch Copyright Act, indicated by the "Taverne" license above, 


\title{
The influence of psychological factors on Health-Related Quality of Life after stroke: a systematic review
}

\author{
Maria L. van Mierlo, Carin Schröder ${ }^{1}$, Caroline M. van Heugten ${ }^{2,3}$, Marcel W. M. Post ${ }^{1}$, \\ Paul L. M. de Kortt ${ }^{4}$, and Johanna M. A. Visser-Meily ${ }^{1 *}$
}

\begin{abstract}
Background and purpose Many stroke patients experience problems with health-related quality of life, but much of the variance of health-related quality of life after stroke remains unexplained. Health-related quality of life may be influenced by psychological factors, as these factors reflect the way people approach situations and react to stressful situations. The aim of this study was to systematically examine the relationship between psychological factors and health-related quality of life after stroke.

Summary of review A systematic literature search was conducted in online databases PubMed, Embase, PsycINFO, and CINAHL in November 2011. A total of nine studies were included. Personality (i.e. problems of temperament and personality functions and neuroticism) was moderately negatively associated with health-related quality of life $(r=$ 0.26-0.49). Coping (i.e. situational and personal adaptation), internal locus of control, self-worth (i.e. self-esteem and selfefficacy), and hope and optimism were moderately positively associated with health-related quality of life $(r=0.026-0.81)$. No evidence was found for an association between extraversion and health-related quality of life.

Conclusions There is still a paucity of studies on psychological determinants of poststroke health-related quality of life. The reviewed studies supported the importance of psychological factors, but further research is needed to supplement the available evidence and to examine how psychological factors can be modified to improve health-related quality of life, and at what moment after the stroke these interventions should be given. Key words: psychological factors, quality of life, stroke, systematic review
\end{abstract}

\section{Introduction}

Stroke is a leading cause of mortality and disability in the Western world and is associated with physical, psychological, and social Correspondence: Johanna M. A. Visser-Meily, University Medical Center Utrecht, Department of Rehabilitation and Sports Medicine, P.O. Box 85500, 3508 GA Utrecht, The Netherlands.

E-mail: j.m.a.visser-meily@umcutrecht.nl

${ }^{1}$ Brain Center Rudolf Magnus and Center of Excellence for Rehabilitation Medicine, University Medical Center Utrecht and De Hoogstraat Rehabilitation, Utrecht, The Netherlands

${ }^{2}$ Department of Psychiatry and Neuropsychology, School for Mental Health and Neuroscience, Maastricht University, Maastricht, The Netherlands

${ }^{3}$ Department of Neuropsychology and Psychopharmacology, Maastricht University, Maastricht, The Netherlands

${ }^{4}$ Department of Neurology, St Elisabeth Hospital, Tilburg, The Netherlands

Received: 20 November 2012; Accepted: 16 April 2013; Published online 22 October 2013

Conflicts of interest: None declared.

Funding: This research project is funded by the VSB foundation and the Dutch Heart Foundation, and co-ordinated by ZonMw (Dutch Organization for Health Research and Development).

DOI: 10.1111/ijs.12149 consequences (1-3). Major improvements in acute stroke care have resulted in more people surviving after stroke, but many of them have to cope with the consequences $(4,5)$, experiencing long-term difficulties in terms of social reintegration (4), life satisfaction (6), physical functioning (7), and emotional functioning, including depression and anxiety (8).

The growing number of chronic stroke patients has led to growing interest in the consequences of stroke for health-related quality of life (HRQoL) (3,9-11). HRQoL refers to 'how health impacts on an individual's ability to function and his or her perceived well-being in physical, mental and social domains of life' (12). HRQoL can be seen as an overarching multidimensional construct, comprising different domains of one's life, such as physical, functional, psychological, and social health (9).

The most commonly investigated determinants of poststroke HRQoL are demographic factors, stroke-related factors, and physical impairments. However, they leave much of the variance of HRQoL unexplained $(13,14)$. Psychological factors may influence functioning and HRQoL (3), because these factors reflect the way people approach situations and react to stressful situations $(15,16)$. Psychological factors are part of the contextual factors (personal and environmental factors) defined by the International Classification of Disability, Functioning and Health (ICF) (17).

The importance of psychological factors for HRQoL has already been demonstrated in other chronic conditions $(18,19)$, but an overview of the influence of psychological factors on the HRQoL of stroke patients is still lacking. The only available review (3) describing the determinants of the HRQoL of stroke patients was not systematic and did not focus on psychological factors alone. Consequently, it missed some of the relevant studies (20). Hence, the objective of this study was to systematically examine the relationship between psychological factors and HRQoL poststroke.

\section{Methods}

\section{Eligibility criteria}

Studies that met the following criteria were included: (1) more than $50 \%$ of the study population had suffered a stroke (ischemic or intracerebral hemorrhagic lesion); (2) all patients had to be $\geq 18$ years; (3) the outcome was HRQoL, assessed with a standardized measure; (4) the determinants studied were one or more psychological factors, assessed with a standardized measure. According to the ICF (17), we operationalized psychological factors as 'coping styles, overall behaviour patterns and character style, individual psychological assets and other characteristics, which may play a role in disability at any level, but that are not part of a health condition or health states' (p. 17). 
The review was limited to articles written in English (5) that had been published as original reports (6), with quantitative data (7), in peer-reviewed journals (8); we excluded case reports.

\section{Search strategy and methodological quality assessment}

Articles were identified by searching the databases PubMed, Embase, CINAHL, and PsycINFO on November, 3, 2011. No constraint was placed on the year of publication. The search was conducted in triadic terms, combining a 'stroke' domain with a 'psychological factor' determinant and a 'HRQoL' outcome. Appendix S1 provides an overview of the search strategy used in PubMed, compiled together with an information specialist.

After duplicates had been removed, all articles were evaluated based on title and abstract. The remaining articles were then read in full and critically evaluated based on the inclusion and exclusion criteria. Both steps were conducted independently by two authors (M. L. M., C. S.). In the case of disagreement between the two authors, a third author (J. M. A. V-M.) was consulted for a final judgment. With regard to the selection of articles based on title and abstract, Cohen's kappa was used to calculate concurrence between both authors (M. L. M., C. S.). The reference lists of the selected articles were also examined to find relevant articles to complement the database search.

The methodological quality of all selected studies was assessed independently by M. L. M. and C. S. The level of agreement between their ratings was calculated using the intraclass correlation coefficient (ICC). Methodological quality was scored using an 8-point checklist, ranging from (1) lowest quality to (8) highest quality (18).

\section{Data extraction and analysis}

Correlation coefficients and standardized $\beta$ coefficients were the most frequently reported statistics in the selected articles. We considered correlation coefficients to be weak if they were below $0 \cdot 3$, moderate between $0 \cdot 3$ and $0 \cdot 5$, and strong above $0 \cdot 5(21)$. The unique proportion of the variance explained by psychological factors (change in $R^{2}$ ) was reported if available.

Psychological factors were classified as consistent determinants if all, or nearly all, bivariate associations reported were statistically significant, and if the majority of these bivariate associations were moderate or strong. Factors were classified as inconsistent if only some of the bivariate associations were statistically significant, or if most of the significant bivariate associations were weak. Factors were considered unrelated to HRQoL if all, or nearly all, bivariate associations were nonsignificant. The results of multivariate regression analyses were used to examine the robustness of the bivariate associations.

\section{Results}

\section{Search results and quality assessment}

The search strategy yielded 1955 articles (Fig. 1). After 561 duplicates had been removed, a further 1353 articles were removed after screening titles and abstracts. After the remaining 41 articles had been read in full, 32 more articles were removed. Agreement between the two authors about the selection of titles and abstracts was good (Cohen's kappa $=0 \cdot 74$ ). The screening of reference lists of included articles produced no additional articles, leaving a total of nine articles for inclusion in the review.

The characteristics of the nine articles are presented in Table 1. All nine articles had been written after 2000 and six of them since 2006. Only two studies had used longitudinal analyses, while six had longitudinal designs. Agreement between the two authors on methodological quality was sufficient $(\mathrm{ICC}=0 \cdot 66)$. On an 8 -point scale the average methodological quality score was $5 \cdot 3$ (range 3-7). Most studies attained a methodological quality score of between 4 and 6 (Appendix S2).

\section{Psychological factors}

A total of six psychological factors were measured: personality, coping, internal locus of control, self-worth, hope, and optimism. The different instruments used to measure these psychological factors are presented in Table 2 and the data extraction is presented in Table 3. Three articles subdivided HRQoL into mental HRQoL and physical HRQoL. The relationships between psychological factors and these subdomains are presented in the text, but not in Table 3.

\section{Personality}

Experiencing problems of temperament and personality functions, an ICF category that was not further specified, was moderately associated with lower HRQoL at six-weeks, three-months, and one-year poststroke. In the regression analysis, problems of temperament and personality functions were most strongly associated with lower HRQoL at one-year poststroke (11).

Neuroticism was moderately associated with lower HRQoL at discharge and five-months after discharge, but not at two-months and 9-12 months after discharge (22). Furthermore, neuroticism one-week before discharge from the hospital was associated with lower mental HRQoL $(\beta=-0 \cdot 27)$, but not with physical HRQoL one-year after discharge (23). In addition, extraversion was not associated with mental and physical HRQoL (23).

\section{Coping}

Situational adaptation was not related to HRQoL at discharge and two-months after discharge, but was moderately to strongly related to higher HRQoL at five-months and 9-12 months after discharge (22). In contrast to these cross-sectional data, three regression analyses found no relationship between situational adaptation at discharge and HRQoL 9-12 months after discharge (24).

Personal adaptation was weakly to moderately related to higher HRQoL at all time points, except at discharge. Personal adaptation at discharge was related to higher HRQoL 9-12 months after discharge in all three regression analyses.

Religious and spiritual coping 2.5 years poststroke was not associated with overall HRQoL, but was moderately associated with higher mental HRQoL $(r=.43)(25)$.

\section{Internal locus of control}

Internal locus of control was moderately to strongly associated with higher HRQoL 12 and 18 months poststroke $(r=0 \cdot 32)$. Internal locus of control was also associated with higher physical 


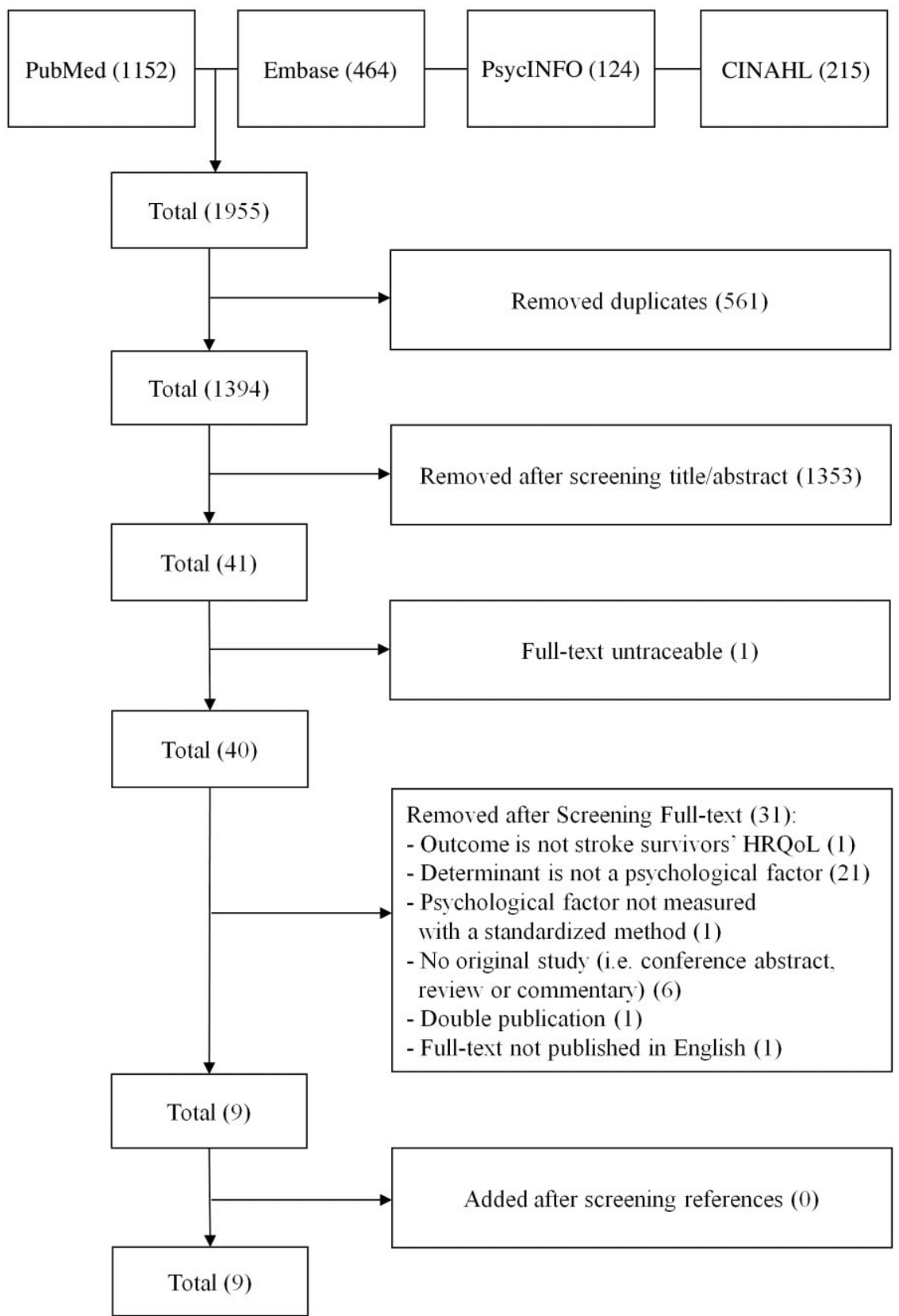

Fig. 1 Search and selection of eligible articles. HRQoL, healh-related quality of life.

HRQoL $(r=0 \cdot 27)(10)$. Multivariate regression analyses showed similar results for HRQoL (Table 3) and physical HRQoL ( $\beta=0 \cdot 16$ and $\beta=0 \cdot 18)(10)$.

\section{Self-worth}

Self-esteem was strongly associated with higher HRQoL (Table 3) and physical HRQoL 12 and 18 months poststroke $(r=0.45$ and $r=0 \cdot 47$, respectively) (10). The multivariate regression analyses revealed inconsistent results. For physical HRQoL, a significant relationship with self-esteem was found at 12 months $(\beta=0 \cdot 23)$, but not at 14 and 18 months poststroke (10).

Physical self-efficacy was associated with higher HRQoL 17 months poststroke (26). Self-care self-efficacy was strongly associated with higher HRQoL at one-month and six-months post- stroke. However, these associations were not significant in the multivariate regression analyses (27).

\section{Hope}

Hope was strongly associated with higher HRQoL at a mean of $2 \cdot 5$ years poststroke. This relationship was still significant in a multivariate regression analysis with control variables (20).

\section{Optimism}

Optimism was strongly associated with higher HRQoL and was moderately associated with higher physical HRQoL $(r=0.21$ and $r=0.39$ ) (10). However, only one of the three associations remained significant in the regression analyses, while none of the associations remained significant for physical HRQoL (10). 


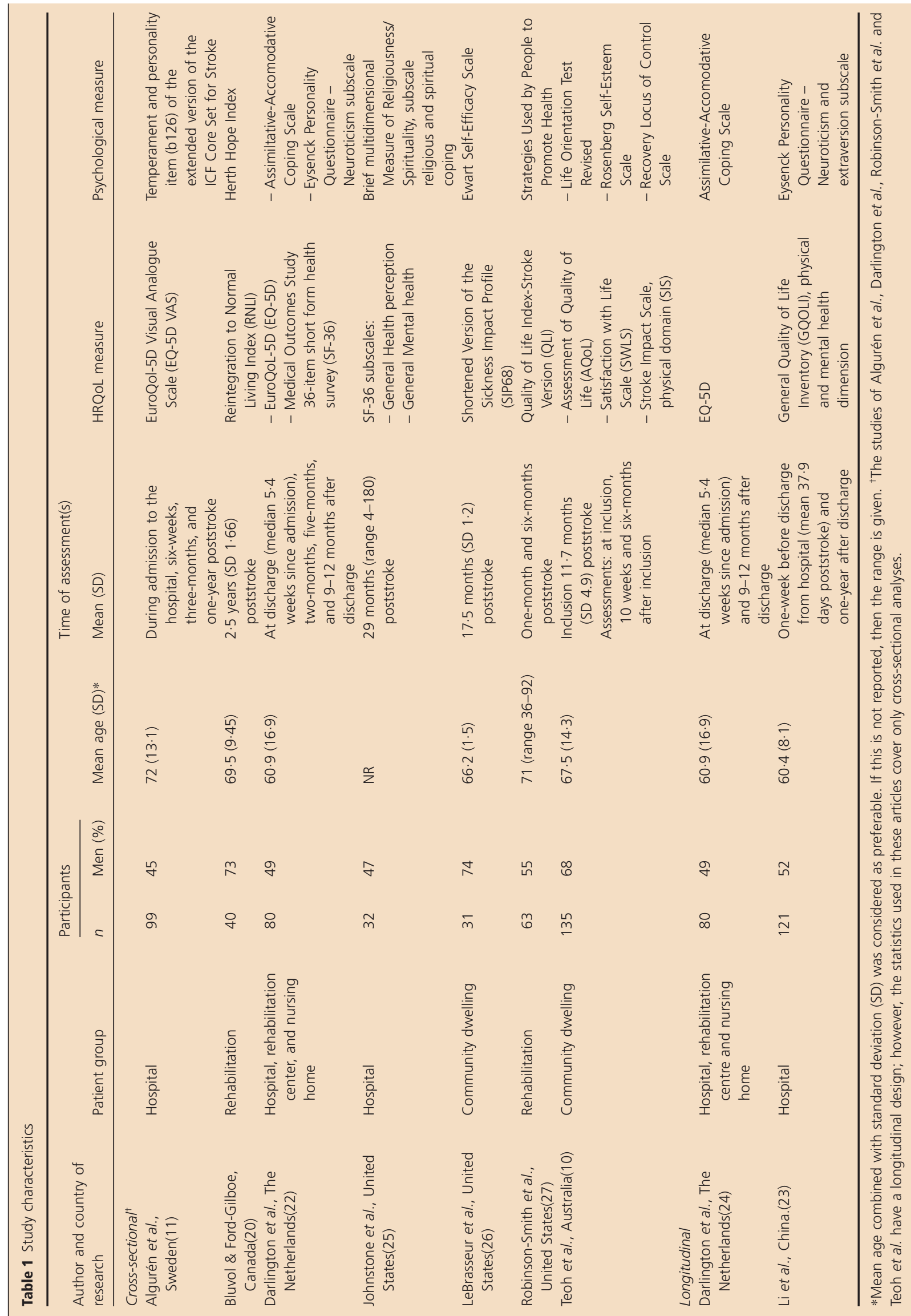


Table 2 Psychological factors and measures

\begin{tabular}{|c|c|c|c|c|c|}
\hline $\begin{array}{l}\text { Psychological } \\
\text { factor }\end{array}$ & Subtypes & Psychological measure (ref.) & $\begin{array}{l}\text { Number of } \\
\text { items }\end{array}$ & Description variable & Scoring \\
\hline \multirow[t]{3}{*}{ Personality } & $\begin{array}{l}\text { Temperament } \\
\text { and } \\
\text { personality } \\
\text { functions }\end{array}$ & $\begin{array}{l}\text { Temperament and } \\
\text { personality functions } \\
\text { item (b126) of the } \\
\text { Extended version of the } \\
\text { ICF Core Set for Stroke } \\
\text { (11) }\end{array}$ & 1 & $\begin{array}{l}\text { The extent of a person's problems in } \\
\text { temperament and personality } \\
\text { functions (11). }\end{array}$ & $\begin{array}{l}\text { 5-point scale ranging from 'no } \\
\text { problem' (0) to 'complete } \\
\text { problem' (4). A higher score } \\
\text { indicates more problems. }\end{array}$ \\
\hline & Neuroticism & $\begin{array}{l}\text { Eysenck Personality } \\
\text { Questionnaire - subscale } \\
\text { neuroticism }(22,23)\end{array}$ & 12 & $\begin{array}{l}\text { Emotional instability (28); e.g. Does } \\
\text { your mood often go up and } \\
\text { down? }\end{array}$ & $\begin{array}{l}\text { Items are scored as 'yes' (1) or 'no' } \\
\text { (0). A higher sum score indicates a } \\
\text { higher level of neuroticism. }\end{array}$ \\
\hline & Extraversion & $\begin{array}{l}\text { Eysenck Personality } \\
\text { Questionnaire - subscale } \\
\text { extraversion (23) }\end{array}$ & 12 & $\begin{array}{l}\text { The tendency of having thoughts } \\
\text { and activities satisfied by things } \\
\text { outside the self (28); e.g. Are you } \\
\text { a talkative person? }\end{array}$ & $\begin{array}{l}\text { Items are scored as 'yes' (1) or 'no' } \\
\text { (0). A higher sum score indicates a } \\
\text { higher level of extraversion. }\end{array}$ \\
\hline \multirow[t]{3}{*}{ Coping } & $\begin{array}{l}\text { Situational } \\
\text { adaptation }\end{array}$ & $\begin{array}{l}\text { Assimilative - } \\
\text { Accommodative Coping } \\
\text { Scale (Tenacious Goal } \\
\text { Pursuit, TGP) }(22,24)\end{array}$ & 15 & $\begin{array}{l}\text { Refers to the coping strategy that is } \\
\text { aimed at actively adjusting } \\
\text { circumstances to personal } \\
\text { preferences (24); e.g. When faced } \\
\text { with difficulties I usually double } \\
\text { my efforts. }\end{array}$ & $\begin{array}{l}\text { 5-point scale ranging from } \\
\text { 'completely agree' (0) to } \\
\text { 'completely disagree' (4). Mean } \\
\text { scores are calculated. Higher } \\
\text { scores indicate better use of } \\
\text { situational adaptation. }\end{array}$ \\
\hline & $\begin{array}{l}\text { Personal } \\
\text { adaptation }\end{array}$ & $\begin{array}{l}\text { Assimilative - } \\
\text { Accommodative Coping } \\
\text { Scale (Flexible Goal } \\
\text { Adjustment) }(22,24)\end{array}$ & 15 & $\begin{array}{l}\text { Refers to the coping strategy } \\
\text { whereby the patient attempts to } \\
\text { accept the consequences of the } \\
\text { stroke by adjusting personal } \\
\text { preferences and goals (24); e.g. I } \\
\text { adapt quite easily to changes in } \\
\text { plans or circumstances. }\end{array}$ & $\begin{array}{l}\text { 5-point scale ranging from } \\
\text { 'completely agree' (0) to } \\
\text { 'completely disagree' (4). Mean } \\
\text { scores are calculated. Higher } \\
\text { scores indicate better use of } \\
\text { personal adaptation. }\end{array}$ \\
\hline & $\begin{array}{l}\text { Religious/spiritual } \\
\text { coping }\end{array}$ & $\begin{array}{l}\text { Brief multidimensional } \\
\text { measure of } \\
\text { religiousness/spirituality- } \\
\text { subscale religious and } \\
\text { spiritual coping (25) }\end{array}$ & 7 & $\begin{array}{l}\text { The extent in which a Higher power } \\
\text { is seen as benevolent and } \\
\text { supportive or punishing and } \\
\text { abandoning ( } 25) \text {; e.g. I look to a } \\
\text { higher power for strength, } \\
\text { support, and guidance. }\end{array}$ & $\begin{array}{l}\text { 6-point and 4-point scales ranging } \\
\text { from 'many times a day' (1) to } \\
\text { 'never or almost never' (6) and } \\
\text { 'strongly agree' (1) to 'strongly } \\
\text { disagree' (4). Lower scores are } \\
\text { indicative of a higher degree of } \\
\text { spiritual coping. }\end{array}$ \\
\hline $\begin{array}{l}\text { Internal locus } \\
\text { of control }\end{array}$ & $\begin{array}{l}\text { Perceived } \\
\text { control over } \\
\text { the course of } \\
\text { recovery }\end{array}$ & $\begin{array}{l}\text { Recovery locus of control } \\
\text { scale (10) }\end{array}$ & 9 & $\begin{array}{l}\text { Measures internal and external } \\
\text { control on a single dimension. } \\
\text { Internal locus of control is the } \\
\text { degree to which an individual } \\
\text { believes the occurrence of } \\
\text { reinforcements is contingent on } \\
\text { his or her own behavior (29); e.g. } \\
\text { my own contribution to my } \\
\text { recovery doesn't account for } \\
\text { much. }\end{array}$ & $\begin{array}{l}\text { 5-point response, with five items } \\
\text { reflecting internal beliefs and four } \\
\text { items reflecting external beliefs. A } \\
\text { single sum score is obtained. A } \\
\text { high score indicates a strong } \\
\text { internal locus of control and a low } \\
\text { score a strong external locus of } \\
\text { control. }\end{array}$ \\
\hline \multirow[t]{3}{*}{ Self-worth } & $\begin{array}{l}\text { Physical } \\
\quad \text { self-efficacy }\end{array}$ & $\begin{array}{l}\text { Ewart self-efficacy scale } \\
\text { (26) }\end{array}$ & & $\begin{array}{l}\text { Self-perceived confidence to perform } \\
\text { a number of physical tasks }(26) ; \\
\text { e.g. climbing stairs }\end{array}$ & $\begin{array}{l}\text { Scores range from } 0 \text { to } 100 . \text { A } \\
\text { higher score indicates higher levels } \\
\text { of self-efficacy. }\end{array}$ \\
\hline & $\begin{array}{l}\text { Self-care } \\
\text { self-efficacy }\end{array}$ & $\begin{array}{l}\text { Strategies used by people } \\
\text { to promote health }(27)\end{array}$ & 36 & $\begin{array}{l}\text { Confidence in self-care behaviors } \\
(27) ; \text { e.g. I have confidence in } \\
\text { finding a way to help me through } \\
\text { this time. }\end{array}$ & $\begin{array}{l}\text { 5-point scale ranging from 'very little } \\
\text { confidence' (1) to 'quite a lot } \\
\text { confidence' (5). A higher sum } \\
\text { score indicates higher levels of } \\
\text { self-care self-efficacy. }\end{array}$ \\
\hline & Self-esteem & $\begin{array}{l}\text { Rosenberg self-esteem } \\
\text { scale (10) }\end{array}$ & 10 & $\begin{array}{l}\text { An overall evaluation of one's } \\
\text { self-worth (10); e.g. on the whole } \\
\text { I am satisfied with myself. }\end{array}$ & $\begin{array}{l}\text { 4-point scale ranging from 'strongly } \\
\text { disagree' (0) to 'strongly agree' } \\
\text { (3). A higher sum score indicates } \\
\text { higher levels of self-esteem. }\end{array}$ \\
\hline Hope & & Herth Hope index (20) & 12 & $\begin{array}{l}\text { A multidimensional life force, which } \\
\text { is characterized by an expectation } \\
\text { of achieving a future good that is } \\
\text { realistic and significant to the } \\
\text { person (30); e.g. I have a positive } \\
\text { outlook toward life. }\end{array}$ & $\begin{array}{l}\text { 4-point scale ranging from 'strongly } \\
\text { disagree' (1) to 'strongly agree' } \\
\text { (4). A higher sum score indicates a } \\
\text { higher level of hope. }\end{array}$ \\
\hline Optimism & & $\begin{array}{l}\text { Life orientation test- revised } \\
\text { (10) }\end{array}$ & $\begin{array}{l}10 \text { (including } \\
\text { four filler } \\
\text { items) }\end{array}$ & $\begin{array}{l}\text { This scale measures dispositional } \\
\text { optimism, which means that a } \\
\text { person has the tendency to expect } \\
\text { the occurrence of good outcomes } \\
\text { in one's life (31); e.g. in uncertain } \\
\text { times, I usually expect the best. }\end{array}$ & $\begin{array}{l}\text { 5-point scale ranging from 'strongly } \\
\text { disagree' (0) to 'strongly agree' } \\
\text { (5). A higher sum score represents } \\
\text { higher levels of optimism. }\end{array}$ \\
\hline
\end{tabular}


Table 3 Relationship between overall Health-Related Quality of Life (HRQoL) and psychological factors after stroke

\begin{tabular}{|c|c|c|c|c|c|}
\hline & \multicolumn{5}{|l|}{ Overall HRQoL } \\
\hline & Time of assessment & HRQoL measure & $r$ & $\mathrm{~b} / \beta / \Delta R^{2}$ & Reference \\
\hline \multicolumn{6}{|l|}{ Personality } \\
\hline \multirow{3}{*}{$\begin{array}{l}\text { Temperament and } \\
\text { personality functions }\end{array}$} & Six-weeks poststroke & EQ-5D VAS & $-0.323 * *$ & $b=-17 \cdot 2 * * *+$ & (11) \\
\hline & Three-months poststroke & & $-0 \cdot 260 *$ & ns & \\
\hline & One-year poststroke & & $-0 \cdot 485 * * *$ & $b=-18.6 * * *+$ & \\
\hline \multirow[t]{4}{*}{ Neuroticism } & $\begin{array}{l}\text { At discharge from hospital, rehabilitation } \\
\text { center, or nursing home }\end{array}$ & EQ-5D & $\mathrm{nr}$ & $\beta=-0.406 * *$ & $(22)$ \\
\hline & Two-months after discharge & & $\mathrm{nr}$ & ns & \\
\hline & Five-months after discharge & & $\mathrm{nr}$ & $\beta=-0.262 *$ & \\
\hline & 9-12 months after discharge & & $\mathrm{nr}$ & ns & \\
\hline \multicolumn{6}{|l|}{ Coping } \\
\hline \multirow[t]{8}{*}{ Situational adaptation (SA) } & $\begin{array}{l}\text { At discharge from hospital, rehabilitation } \\
\text { center, or nursing home }\end{array}$ & EQ-5D & 0.026 & $\beta=0.098$ & $(22)$ \\
\hline & Two-months after discharge & $E Q-5 D$ & 0.231 & $\beta=0.163$ & \\
\hline & & SF-36 & $\mathrm{nr}$ & $\beta=0.255^{*}$ & \\
\hline & Five-months after discharge & EQ-5D & $0.464 * * *$ & $\beta=0.399 * *$ & \\
\hline & & SF-36 & $\mathrm{nr}$ & $\beta=0.378 * *$ & \\
\hline & 9-12 months after discharge & $E Q-5 D$ & $0.435 * * *$ & $\beta=0.443 * * *$ & \\
\hline & & SF-36 & $\mathrm{nr}$ & $\beta=0.453 * * *$ & \\
\hline & $\begin{array}{l}\text { SA at discharge and HRQoL 9-12 months } \\
\text { after discharge (Longitudinal analysed) }\end{array}$ & EQ-5D & $\mathrm{nr}$ & $\beta=0.068-0.074$ & $(24)$ \\
\hline \multirow[t]{8}{*}{ Personal adaptation (PA) } & $\begin{array}{l}\text { At discharge from hospital, rehabilitation } \\
\text { center, or nursing home }\end{array}$ & $E Q-5 D$ & $0 \cdot 100$ & $\beta=0.077$ & $(22)$ \\
\hline & Two-months after discharge & $E Q-5 D$ & $0.271 *$ & $\beta=0.196$ & \\
\hline & & SF-36 & $\mathrm{nr}$ & $\beta=0.232$ & \\
\hline & Five-months after discharge & EQ-5D & $0.279 *$ & $\beta=0.196$ & \\
\hline & & SF-36 & & $\beta=0.250 *$ & \\
\hline & 9-12 months after discharge & $E Q-5 D$ & $0.362 * *$ & $\beta=0.316 * *$ & \\
\hline & & SF-36 & $\mathrm{nr}$ & $\beta=0.382 * *$ & \\
\hline & $\begin{array}{l}\text { PA at discharge and HRQoL 9-12 months } \\
\text { after discharge (Longitudinal analysed) }\end{array}$ & EQ-5D & $\mathrm{nr}$ & $\beta=0.116 *-0.126 * *$ & $(24)$ \\
\hline Religious/spiritual coping & Mean 29 months poststroke & SF-36 & $0 \cdot 17$ & & (25) \\
\hline \multirow[t]{6}{*}{ Internal Locus of control } & Mean 12 months poststroke & AQoL & $0.50 * * *$ & $\beta=0.29 * * *$ & (10) \\
\hline & & SWLS & $0.40 * * *$ & $\beta=0.16^{*}$ & \\
\hline & Mean 14 months post stroke & AQoL & $\mathrm{nr}$ & $\beta=0.18^{*}$ & \\
\hline & & SWLS & $\mathrm{nr}$ & ns & \\
\hline & Mean 18 months post stroke & AQoL & $0.30 * * *$ & ns & \\
\hline & & SWLS & $0.29 * * *$ & ns & \\
\hline \multicolumn{6}{|l|}{ Self-worth } \\
\hline \multirow[t]{6}{*}{ Self-esteem } & Mean 12 months poststroke & AQoL & $0.58 * * *$ & ns & $(10)$ \\
\hline & & SWLS & $0.59 * * *$ & $\beta=0.21 *$ & \\
\hline & Mean 14 months poststroke & AQoL & $\mathrm{nr}$ & $\beta=0.20 *$ & \\
\hline & & SWLS & $\mathrm{nr}$ & $\beta=0.27 * *$ & \\
\hline & Mean 18 months poststroke & AQoL & $0.60 * * *$ & ns & \\
\hline & & SWLS & $0.68 * * *$ & $\beta=0.41 * * *$ & \\
\hline Physical self-efficacy & Mean 17 months poststroke & SIP68 & $\mathrm{nr}$ & $\mathrm{b}=-60 \cdot 70 * * * \neq / \Delta \mathrm{R} 2=0.21$ & (26) \\
\hline \multirow{2}{*}{ Self-care self-efficacy } & One-month poststroke & QLI & $0.66 * * *$ & ns & (27) \\
\hline & Six-months poststroke & & $0.81 * * *$ & ns & \\
\hline Hope & Mean 2.5 years poststroke & RNLI & $0.59 * * *$ & $\beta=0.351 *$ & $(20)$ \\
\hline \multirow[t]{6}{*}{ Optimism } & Mean 12 months poststroke & AQoL & $0.39 * * *$ & ns & (10) \\
\hline & & SWLS & $0.49 * * *$ & ns & \\
\hline & Mean 14 months poststroke & AQoL & $\mathrm{nr}$ & ns & \\
\hline & & SWLS & $\mathrm{nr}$ & ns & \\
\hline & Mean 18 months poststroke & AQoL & $0.53 * * *$ & $\beta=0.21 * *$ & \\
\hline & & SWLS & $0.60 * * *$ & ns & \\
\hline
\end{tabular}

$* P<0.05, * * P<0.01, * * * P<0.001$

${ }^{+}$The given results of the regression analyses of temperament and personality functions were calculated with the Body functions component of the ICF only. The results of the regression analyses in which all three components of the ICF are represented are not significant for six-weeks and three-months poststroke, but are significant at six-months poststroke, $b=-16 \cdot 7 * * *$.

FHigher scores on the SIP68 indicate more health-related quality of life problems.

$\mathrm{ns}$, not significant; $\mathrm{nr}$, not reported; $r$, correlation; $\mathrm{b}$, unstandardized regression coefficient; $\beta$, standardized regression coefficient; $\Delta R^{2}$, explained variance of the determinant; EQ-5D VAS, EuroQol-5D Visual Analogue Scale; SF-36, Medical Outcomes Study 36-item short form health survey; AQoL, Assessment of Quality of Life; SWLS, Satisfaction with Life Scale; SIP68, Shortened Version of the Sickness Impact Profile; QLI, Quality of Life Index-Stroke Version; RNLI, Reintegration to Normal Living Index. 


\section{Discussion}

The aim of the present review was to systematically examine the relationships between psychological factors and HRQoL poststroke. Negative personality characteristics (i.e. problems of temperament and personality functions and neuroticism) were moderately associated with lower HRQoL. Coping (i.e. situational and personal adaptation, and religious and spiritual coping), internal locus of control, self-worth (i.e. self-esteem and selfefficacy), hope, and optimism were moderately associated with higher HRQoL.

\section{Negative determinants}

The experience of problems with temperament and personality functions was already associated with lower HRQoL six-weeks poststroke. The negative associations between neuroticism and HRQoL are in accordance with those found in studies among patients with other chronic conditions, such as asthma and head and neck cancer $(15,32)$. Patients with high scores for neuroticism may experience lower HRQoL because they focus more on their symptoms and are likely to report more symptoms (33).

\section{Positive determinants}

Positive associations with HRQoL were found for situational and personal adaptation. There are several classification systems for coping. A frequently used classification system divides coping into problem-focused (e.g. actively addressing the problem) and emotion-focused (e.g. accepting situations more easily) coping styles (34). According to this classification, situational and personal adaptation can be classified as problem-focused and emotion-focused coping styles, respectively. Darlington et al. (22) expected that in the first months after discharge, higher HRQoL would be related to high levels of problem-focused coping styles, whereas higher HRQoL five-months after discharge would be related to high levels of emotion-focused coping styles. The results in the present study were not entirely in accordance with this expectation. Situational adaptation showed a relationship with HRQoL from five-months after discharge, and personal adaptation already from two-months after discharge. Furthermore, at five-months after discharge, correlations between situational adaptation and HRQoL were somewhat higher than between personal adaptation and HRQoL. Recently, Brands et al. (35) suggested that a simultaneous and continuous interaction between both coping styles, that is, pursuing goals and adjusting to the changes where necessary, would be the best combination for the process of adjustment in patients with acquired brain injury. This assumption fits in better with the results reported by Darlington et al. (22), so more research is needed to examine which combination of coping styles is the most beneficial, in terms of HRQoL poststroke. It is interesting that coping became more closely related to HRQoL as more time elapsed after the stroke: there was no association between personal adaptation until two-months after discharge and there was no association between situational adaptation and HRQoL until five-months after discharge. This effect was not studied for the other psychological factors. It might be that physical factors play a more prominent role in determining HRQoL in the acute poststroke phase, whereas psychological factors are more important in the chronic phase.

It is important to know which psychological factors can be modified in order to optimize HRQoL poststroke. Personality is presumed to be a constant factor across a person's life span, in contrast to coping (22). In recent years, positive psychology interventions aimed at strengthening psychological resources, for example self-esteem, have attracted increasing interest (36). Our review found associations of self-worth, hope, optimism, and locus of control with HRQoL. Opportunities to modify these factors by means of therapy, and the effects of such interventions on HRQoL, should be further investigated.

\section{Unrelated determinants}

No associations were found between extraversion and mental and physical HRQoL. However, this was not examined in bivariate correlational analyses, as was done for the other psychological factors. A positive relationship between extraversion and HRQoL has been found in other patient groups, such as asthma patients (15).

\section{Limitations of the literature}

First, the number of included articles and the numbers of patients per article were small; three of the nine studies had fewer than 55 patients (necessary for a correlation of 0.33 or $10 \%$ explained variance to become significant). Second, the included articles were heterogeneous in terms of patient groups, time of assessment, and measures used to assess HRQoL. Third, only two of the nine studies had used longitudinal analyses. Finally, the small number of included articles meant that only a small number of psychological factors were measured, with only one or two articles per psychological factor.

\section{Limitations of this review}

One limitation with respect to this systematic review is the lack of a generally accepted definition of psychological factors. We operationalized psychological factors using the ICF, similar to the way the psychological-personal perspective of the ICF was captured in a study of spinal cord injury (37).

The second limitation was that depression and anxiety were not captured in the operationalization of psychological factors. These concepts are part of the concept of (mental) HRQoL, so that studying depression and anxiety as determinants of HRQoL would result in strong conceptual overlap between determinants and outcomes.

\section{Further research and clinical implications}

More research is needed into psychological characteristics of stroke patients and their impact on HRQoL. Longitudinal studies are particularly needed because they allow causal relationships and effects of time to be identified. It is also important to investigate which psychological factors can be modified by means of therapy, in order to optimize interventions for HRQoL after stroke.

It is important for clinicians to become aware of the relationship between psychological factors, such as personality and coping, and HRQoL poststroke, as this relationship identifies 
treatment targets other than the stroke itself or physical functioning, to improve HRQoL. Monitoring neuroticism and problems of temperament and personality in an early stage poststroke may help identify patients at risk for poor long-term adjustment. Additionally, rehabilitation treatment should attempt to strengthen factors such as hope, optimism, self-worth, and personal and situational adaptation coping styles.

\section{References}

1 World Health Organization. The World Health Report 2003: Shaping the Future. Geneva, World Health Organization, 2003.

2 Bonita R, Mendis S, Truelsen T, Bogousslavsky J, Toole J, Yatsy F. The Global Stroke Initiative. Lancet Neurol 2004; 3:391-3.

3 Carod-Artal FJ, Egido JA. Quality of life after stroke: the importance of a good recovery. Cerebrovasc Dis 2009; 27(Suppl. 1):204-14.

4 Hommel M, Trabucco-Miguel S, Joray S, Naegele B, Gonnet N, Jaillard A. Social dysfunctioning after mild to moderate first-ever stroke at vocational age. J Neurol Neurosurg Psychiatry 2009; 80:371-5.

5 Donnellan C, Hevey D, Hickey A, O'Neill D. Defining and quantifying coping strategies after stroke: a review. J Neurol Neurosurg Psychiatry 2006; 77:1208-18.

6 Ostwald SK, Godwin KM, Cron SG. Predictors of life satisfaction in stroke survivors and spousal caregivers twelve to twenty-four months post discharge from inpatient rehabilitation. Rehabil Nurs 2009; 34:160-74.

7 Van de Port IGL, Kwakkel G, van Wijk I, Lindeman E. Susceptibility to deterioration of mobility long-term after stroke: a prospective cohort study. Stroke 2006; 37:167-71.

8 Bergersen H, Frøslie KF, Sunnerhagen KS, Schanke A. Anxiety, depression, and psychological well-being 2 to 5 years poststroke. J Stroke Cerebrovasc Dis 2010; 19:364-9.

9 Carod-Artal J, Egido JA, González JL, de Seijas EV. Quality of life among stroke survivors evaluated 1 year after stroke: experience of a stroke unit. Stroke 2000; 31:2995-3000.

10 Teoh V, Sims J, Milgrom J. Psychosocial predictors of quality of life in a sample of community-dwelling stroke survivors: a longitudinal study. Top Stroke Rehabil 2009; 16:157-66.

11 Algurén B, Fridlund B, Cieza A, Sunnerhagen KS, Christensson L. Factors associated with health-related quality of life after stroke: a 1-year prospective cohort study. Neurorehabil Neural Repair 2012; 26:266-74.

12 Coons SJ, Rao S, Keininger DL et al. A comparative review of quality of life instruments. Pharmacoeconomics 2000; 17:13-35.

13 Sturm JW, Donnan GA, Dewey HM et al. Quality of life after stroke: the North East Melbourne Stroke Incidence Study (NEMESIS). Stroke 2004; 35:2340-5.

14 Nichols-Larsen DS, Clark PC, Zeringue A, Greenspan A, Blanton S. Factors influencing stroke survivors' quality of life during subacute recovery. Stroke 2005; 36:1480-4.

15 Van de Ven MOM, Engels RCME. Quality of life of adolescents with asthma: the role of personality, coping strategies, and symptom reporting. J Psychosom Res 2011; 71:166-73.

16 Visser-Meily JMA, Rhebergen ML, Rinkel GJE, van Zandvoort MJ, Post MWM. Long-term health-related quality of life after aneurysmal subarachnoid hemorrhage: relationship with psychological symptoms and personality characteristics. Stroke 2009; 40:1526-29.

17 World Health Organization. International Classification of Functioning, Disability and Health: ICF. Geneva, World Health Organization, 2001.

18 Van Leeuwen CMC, Kraaijeveld S, Lindeman E, Post MWM. Associations between psychological factors and quality of life ratings in persons with spinal cord injury: a systematic review. Spinal Cord. 2012; 50:174-87.

19 Hyphantis T, Paika V, Almyroudi A, Kampletsas EO, Pavlidis N. Personality variables as predictors of early non-metastatic colorectal cancer patient's psychological distress and health-related quality of life: a one-year prospective study. J Psychosom Res 2011; 70:41121.

20 Bluvol A, Ford-Gilboe M. Hope, health work and quality of life in families of stroke survivors. J Adv Nurs 2004; 48:322-32.

21 Cohen J. Statistical Power Analysis for the Behavioural Sciences, 2nd edn. Hillsdale, NJ, Lawrence Erlbaum Associates, 1988.

22 Darlington ASE, Dippel DWJ, Ribbers GM, van Balen R, Passchier J, Busschbach JJV. Coping strategies as determinants of quality of life in stroke patients: a longitudinal study. Cerebrovasc Dis 2007; 23:401-7.

$23 \mathrm{Li} \mathrm{L}$, Young D, Hu Z. Longitudinal study of quality of life following stroke. Hong Kong J Psychiatry 2001; 11:17-22.

24 Darlington ASE, Dippel DWJ, Ribbers GM, van Balen R, Passchier J, Busschbach JJV. A prospective study on coping strategies and quality of life in patients after stroke, assessing prognostic relationships and estimates of cost-effectiveness. J Rehabil Med 2009; 41:237-41.

25 Johnstone B, Franklin KL, Yoon DP, Burris J, Shigaki C. Relationships among religiousness, spirituality, and health for individuals with stroke. J Clin Psychol Med Settings 2008; 15:308-13.

26 LeBrasseur NK, Sayers SP, Ouellette MM, Fielding RA. Muscle impairments and behavioural factors mediate functional limitations and disability following stroke. Phys Ther 2006; 86:1342-50.

27 Robinson-Smith G, Johnston MV, Allen J. Self-care self-efficacy, quality of life, and depression after stroke. Arch Phys Med Rehabil 2000; 81:460-64.

28 Sanderman R, Arrindell WA, Ranchor AV, Eysenck HJ, Eysenck SBG. Het Meten Van Persoonlijkheidskenmerken Met De Eysenck Personality Questionnaire (EPQ): Een Handleiding. Groningen, Noordelijk Centrum voor Gezondheidsvraagstukken, 1995.

29 Rotter JB. Generalized expectancies for internal versus external control of reinforcement. Psychol Monogr 1966; 1:1-28.

30 Dufault K, Martocchio BC. Symposium on compassionate care and the dying experience. Hope: its spheres and dimensions. Nurs Clin North Am 1985; 20:379-91.

31 Scheier MF, Carver CS. Optimism, Coping and Health: assessment and implications of generalized outcome expectancies. Health Psychol 1985; 4:219-47.

32 Aarstad AKH, Aastrad HJ, Olofsson J. Personality and choice of coping predict quality of life in head and neck cancer patients during followup. Acta Oncol 2008; 47:879-90.

33 Larsen RJ. Neuroticism and selective encoding and recall of symptoms: evidence from a combined concurrent-retrospective study. J Pers Soc Psychol 1992; 62:480-8.

34 Folkman S, Lazarus RS. An analysis of coping in a middle-aged community sample. J Health Soc Behav 1980; 21:219-39.

35 Brands IMH, Wade DT, Stapert SZ, van Heugten CM. The adaptation process following acute onset disability: an interactive twodimensional approach applied to acquired brain injury. Clin Rehabil 2012; 26:840-52.

36 Sin NL, Lyubomirsky S. Enhancing well-being and alleviating depressive symptoms with positive psychology interventions: a practicefriendly meta-analysis. J Clin Psychol 2009; 65:467-87.

37 Geyh S, Müller R, Peter C et al. Capturing the psychologic-personal perspective in spinal cord injury. Am J Phys Med Rehabil 2011; 90(Suppl.):S79-S96.

\section{Supporting information}

Additional Supporting Information may be found in the online version of this article at the publisher's web-site:

Appendix S1. Methodological quality assessment.

Appendix S2. PubMed search strategy. 